\title{
Tumour budding in oral squamous cell carcinoma: a meta-analysis
}

\begin{abstract}
Alhadi Almangush*,1,2,3, Matti Pirinen ${ }^{4,5,6}$, Ilkka Heikkinen ${ }^{1,2}$, Antti A Mäkitie ${ }^{7}$, Tuula Salo 2,8,9,10 and IImo Leivo ${ }^{11}$

${ }^{1}$ Department of Patholosgy, University of Helsinki, Haartmaninkatu 3, PO Box 21, Helsinki FIN-00014, Finland; ${ }^{2}$ Department of Oral and Maxillofacial Diseases, University of Helsinki, Haartmaninkatu 8, PO Box 63, Helsinki Fl-00014, Finland; ${ }^{3}$ Institute of Dentistry, University of Misurata, PO Box 2478, Misurata, Libya; ${ }^{4}$ Institute for Molecular Medicine Finland (FIMM), University of Helsinki, Helsinki FIN-00014, Finland; ${ }^{5} \mathrm{Helsinki}$ Institute for Information Technology HIIT and Department of Mathematics and Statistics, University of Helsinki, Helsinki FIN-00014, Finland; 'Department of Public Health, University of Helsinki, Helsinki FIN-00014, Finland; ${ }^{7}$ Department of Otorhinolaryngology - Head and Neck Surgery, Helsinki University Hospital and University of Helsinki, Kasarminkatu 11-13, Helsinki Fl-00130, Finland; ${ }^{8}$ Helsinki University Hospital, Helsinki FIN-00014, Finland; ${ }^{9}$ Research Group of Cancer Research and Translational Medicine, Medical Faculty, University of Oulu, PO Box 5281, Oulu 90014, Finland; ${ }^{10}$ Medical Research Center, Oulu University Hospital, Oulu 90220, Finland and ${ }^{11}$ Department of Pathology, University of Turku, Kiinamyllynkatu 10, Turku 20520, Finland
\end{abstract}

Background: Tumour budding has been reported as a promising prognostic marker in many cancers. This meta-analysis assessed the prognostic value of tumour budding in oral squamous cell carcinoma (OSCC).

Methods: We searched OvidMedline, PubMed, Scopus and Web of Science for articles that studied tumour budding in OSCC. We used reporting recommendations for tumour marker (REMARK) criteria to evaluate the quality of studies eligible for metaanalysis.

Results: A total of 16 studies evaluated the prognostic value of tumour budding in OSCC. The meta-analysis showed that tumour budding was significantly associated with lymph node metastasis (odds ratio $=7.08,95 \% \mathrm{Cl}=1.75-28.73$ ), disease-free survival (hazard ratio $=1.83,95 \% \mathrm{Cl}=1.34-2.50$ ) and overall survival (hazard ratio $=1.88,95 \% \mathrm{Cl}=1.25-2.82$ ).

Conclusions: Tumour budding is a simple and reliable prognostic marker for OSCC. Evaluation of tumour budding could facilitate personalised management of OSCC.

Oral squamous cell carcinoma (OSCC) is the most common malignancy of the oral cavity and constitutes the majority of head and neck squamous cell carcinomas. According to a recent report, $\sim 300000$ new cases of oral cancer were diagnosed worldwide in 2012, and with a consequent 145000 cancer-related deaths (Ferlay et al, 2015). The incidence of OSCC has increased in many countries and especially in young people (Muller et al, 2008; Korvala et al, 2017). In the Western world, the main aetiological factors for OSCC are tobacco and alcohol consumption. Chewing of Areca nuts and the use of snuff are the classic risk factors in the Indian population. The 5-year survival rate of OSCC patients is relatively low, and especially the patients with recurrence have poor outcomes. Identifying cases at risk for recurrence remains challenging.

Many histopathologic prognostic parameters (e.g., tumour grade, depth of invasion, perineural invasion, lymphovascular invasion, lymphocytic host response and mitotic activity) are usually evaluated in haematoxylin- and eosin- (H-E) stained

*Correspondence: Dr A Almangush; E-mail: alhadi.almangush@helsinki.fi or alhadi.almangush@gmail.com

Received 29 September 2017; revised 27 October 2017; accepted 30 October 2017; published online 30 November 2017

(C) 2018 Cancer Research UK. All rights reserved $0007-0920 / 18$ 
sections. Such information is included in pathology reports to aid in predicting the behaviour of OSCC. This is paramount for planning of an appropriate and successful management. However, some of these parameters (e.g., tumour grade and lymphocytic response) have not been promising prognosticators, especially in early stage OSCC (Chen et al, 2013; Almangush et al, 2015a). Moreover, recent research has introduced several biomarkers for OSCC, but they are not yet eligible to be included in the pathology report (Soland and Brusevold, 2013; Almangush et al, 2017a). In addition, such biomarkers require additional staining procedures which are not routinely used. Therefore, it is important to identify new powerful prognostic markers that are adaptable to conventional H-E staining.

Tumour budding, defined as the presence of single cancer cell(s) or cluster(s) of less than five cancer cells at the invasive front (IF), has been reported in many cancers as a promising prognostic feature (Kadota et al, 2015; Almangush et al, 2016; Rogers et al, 2016). Tumour budding at the IF (Figure 1) indicates the dissociation of invasive cancer cells from the main tumour mass. Several recent studies have evaluated the significance of tumour budding in OSCC. The aim of the current study was to systematically review the studies on tumour budding in OSCC and to present a meta-analysis of the prognostic value of tumour budding in OSCC. We also discuss the shortcomings in the published studies and provide recommendations for further research to standardise the evaluation method of tumour budding in OSCC.

\section{MATERIALS AND METHODS}

Search protocol. OvidMedline, PubMed, Scopus and Web of Science were searched using the following keywords: ('oral' or 'mouth' or 'tongue' or 'floor of mouth' or 'lip' or 'gingiva' or 'buccal' or 'palate') and ('tumour budding'). Our search was limited to articles in the English language. The end point of the search was May 2017. To ensure inclusion of all relevant articles, we manually searched the reference lists of all eligible studies. When searching and screening the studies, we followed the Preferred Reporting Items for Systematic Review and Meta-Analysis (PRISMA) (Moher et al, 2009).

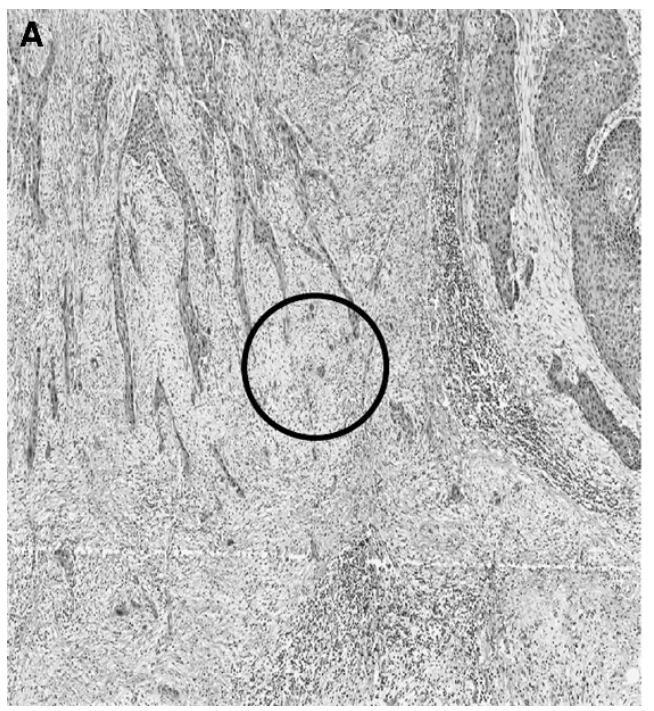

Exclusion criteria. We excluded studies in a language other than English, studies on animal samples and conference abstracts.

Quality assessment. We used reporting recommendations for tumour marker prognostic studies (REMARK) guidelines (Altman et $a l, 2012)$ to assess the quality of studies that evaluated the prognostic value of tumour budding in OSCC. We summarised the main guidelines in Table 1 . Any study that received a score of less than 6 was not included in our meta-analysis.

Statistical methods. The meta-analysis was performed by the 'meta' package (version 4.8-1) in statistical software $\mathrm{R}$ (version 3.4.0). For each analysis, we carried out an inverse varianceweighted fixed-effects analysis. For completeness, a DerSimonianLaird random effects analysis (DerSimonian and Laird, 1986) was also performed. We considered the random effects analysis as our main result to account for heterogeneity between the studies. In addition to the meta-analysed effect sizes, our results also included the estimated proportion of variation in effect sizes due to heterogeneity $\left(I^{2}\right)$ (Higgins and Thompson, 2002) and the DerSimonian-Laird estimate of the variance of the effect sizes $\left(t^{2}\right)$ (DerSimonian and Laird, 1986). We first conducted metaanalyses for each survival end point even if tumour stage, oral subsite or budding cutoff point varied between the studies. To reduce heterogeneity among the included studies, we then conducted additional meta-analyses specifically for studies with early stage cases and for studies from single oral subsite (oral tongue). We also conducted separate meta-analyses for studies with a similar cutoff point of tumour budding.

\section{RESULTS}

Search results. A total of 63 hits were retrieved from searches of databases, and 39 hits were excluded as duplicates. There were 22 studies that had evaluated tumour budding in OSCC (Figure 2). Of these, 16 studies had reported the prognostic value of tumour budding in OSCC (Table 2). The other six studies had evaluated tumour budding in OSCC without providing its prognostic value (Table 3).

Statistical results. A meta-analysis of the prognostic value of tumour budding for lymph node metastasis, disease-free survival and overall survival is summarised in Figures 3-5. For each end

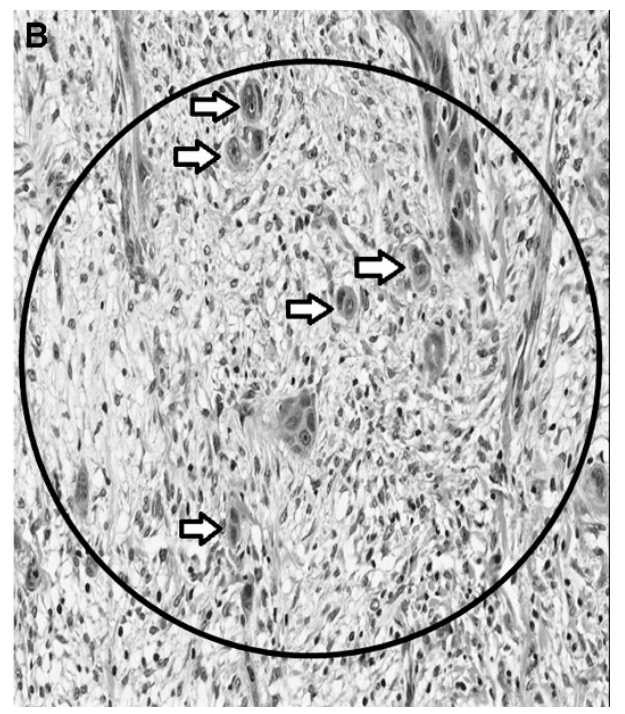

Figure 1. Tumour budding, defined as single cancer cell or clusters of less than five cells at the invasive front of oral squamous cell carcinoma (OSCC). (A) Low magnification $(\times 4)$; and (B) high magnification $(\times 20)$ of the area inside the circle. 
Table 1. Evaluation criteria that have been used to assess the quality of studies evaluated tumour budding in OSCC (adapted from REMARK)

\begin{tabular}{|c|c|}
\hline Checklist & Criteria \\
\hline Introduction & The hypotheses and objectives of the study were clearly explained \\
\hline Cohort description & $\begin{array}{l}\text { Retrospective or prospective cohort with a well-defined study population } \\
\text { Medical treatment of the cases was explained }\end{array}$ \\
\hline Patient data & The basic data such as age, gender, clinical stage and histopathologic grade was provided \\
\hline Evaluation method & Well-described method including the microscopic field/s and the cutoff point. Inter-observer variability was evaluated \\
\hline Prognostic analysis & $\begin{array}{l}\text { The survival end point was defined and/or the relationship between the tumour budding and lymph node metastasis was } \\
\text { studied }\end{array}$ \\
\hline Statistical analysis & $\begin{array}{l}\text { Estimated effect (e.g., hazard ratio, relative risk with their confidence interval), which reveal the relationship between tumour } \\
\text { budding and the survival end point/s } \\
\text { The independence of prognostic value was reported by multivariate analysis }\end{array}$ \\
\hline Classical prognostic factors & $\begin{array}{l}\text { The prognostic value of the classical prognostic factors (e.g., stage and grade) were reported } \\
\text { The relationship between tumour budding and classical prognostic factors was reported }\end{array}$ \\
\hline $\begin{array}{l}\text { Interpretation of the prognostic } \\
\text { value and discussion }\end{array}$ & $\begin{array}{l}\text { Comparison of the current findings with other studies } \\
\text { Strengths and limitations of the current data } \\
\text { Recommendation for further research }\end{array}$ \\
\hline
\end{tabular}

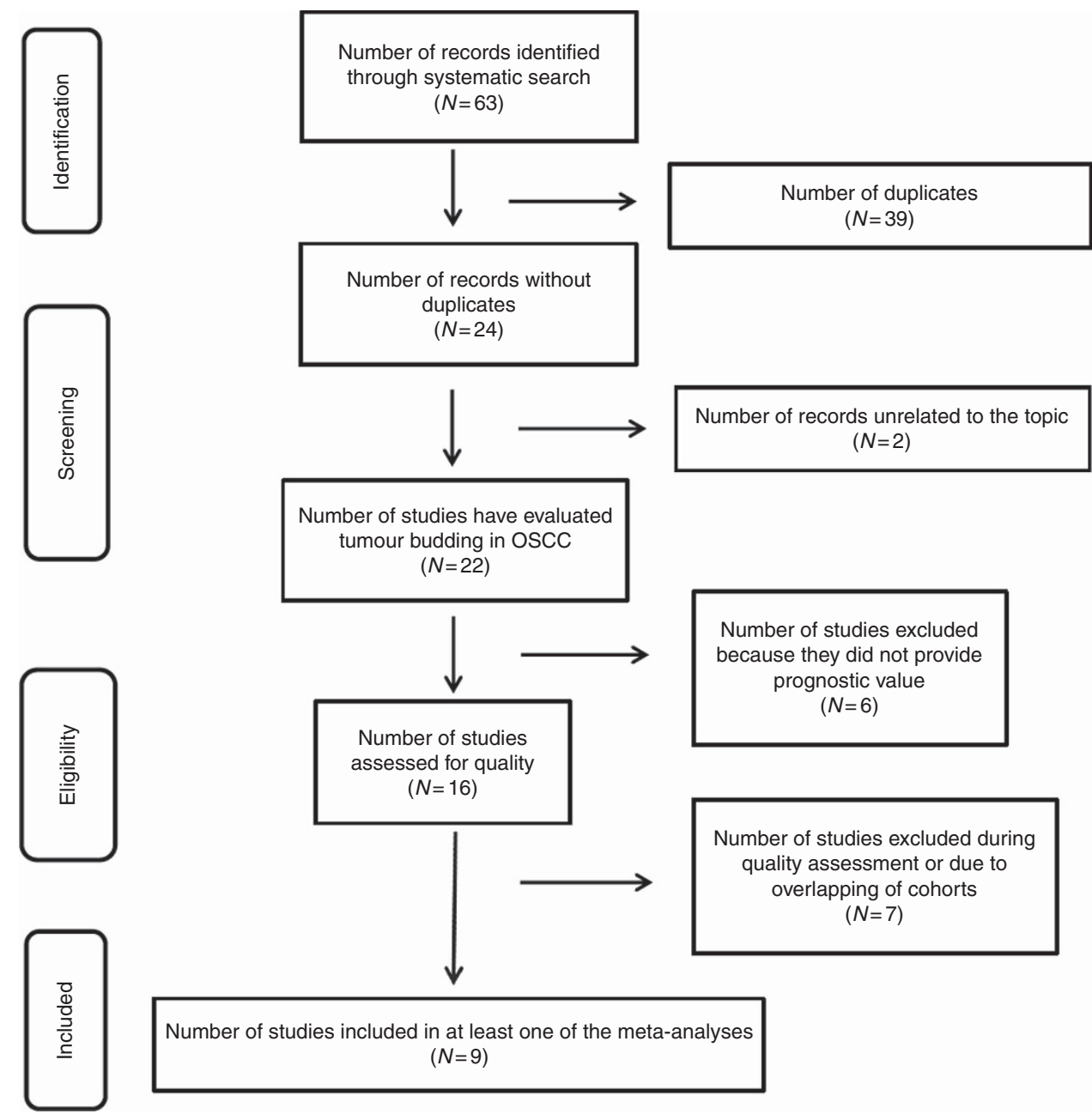

Figure 2. Flow diagram outlining the search strategy and the search results along various steps.

point, there was at least one meta-analysis of three high-quality studies (according to REMARK guidelines; Table 1) that had reported the necessary statistical values (hazard ratio (HR) or odds ratio (OR) and confidence interval (CI)). According to our analyses, there was strong evidence for tumour budding to be considered as a promising prognostic marker for OSCC.

Our meta-analyses of eligible studies with different budding cutoff points for risk stratification indicated that high-grade 
Table 2. Summary of the studies that examined the prognostic value of tumour budding in OSCC

\begin{tabular}{|c|c|c|c|c|c|c|c|c|c|c|c|c|c|}
\hline $\begin{array}{l}\text { (Authors, } \\
\text { year) } \\
\text { Country }\end{array}$ & Cases & Stage & Location & $\begin{array}{l}\text { Follow } \\
\text { up }\end{array}$ & $\begin{array}{l}\text { Primary } \\
\text { treatment }\end{array}$ & Staining & Cutoff & $\%$ & Field & $\begin{array}{l}\text { Survival } \\
\text { analysis }\end{array}$ & HR $(95 \% \mathrm{Cl})$ & $\begin{array}{c}P \\
\text { value }\end{array}$ & Quality \\
\hline $\begin{array}{l}\text { (Wang } \\
\text { et al, 2011) } \\
\text { China }\end{array}$ & 133 & I-IV & Tongue & $\begin{array}{l}65 \\
\text { months }\end{array}$ & Surgery & $\mathrm{H}-\mathrm{E}$ & 5 buds & $44.4 \%$ & $\times 20$ & OS & $\begin{array}{c}3.350 \\
(1.774-6.323) \\
3.029 \\
(1.535-5.977)\end{array}$ & 0.0014 & 8 \\
\hline $\begin{array}{l}\text { (Alman- } \\
\text { gush et al, } \\
\text { 2014) } \\
\text { Finland }\end{array}$ & 233 & cT1-2N0 & Tongue & $\begin{array}{l}67 \\
\text { months }\end{array}$ & Surgery & $\mathrm{H}-\mathrm{E}$ & 5 buds & $34.8 \%$ & $\times 20$ & DSS & $\begin{array}{c}2.00 \\
(1.17-3.40) \\
2.04 \\
(1.17-3.55)\end{array}$ & 0.01 & 7 \\
\hline \multirow[t]{2}{*}{$\begin{array}{l}\text { (Manjula } \\
\text { et al, 2015) } \\
\text { India }\end{array}$} & 33 & T1-T4 & $\begin{array}{l}\text { Gingivo } \\
\text { buccal } \\
\text { complex }\end{array}$ & $\begin{array}{l}15 \\
\text { months }\end{array}$ & Surgery & $\mathrm{H}-\mathrm{E}$ & $\begin{array}{l}10 \\
\text { buds }\end{array}$ & $63.6 \%$ & NA & DFS & $\begin{array}{c}1.32 \\
(0.59-2.95)\end{array}$ & 0.49 & 6 \\
\hline & & & & & & & & . & & LNM & $\begin{array}{c}\text { OR } 7.5 \\
(1.49-37.66)\end{array}$ & 0.014 & \\
\hline \multirow[t]{3}{*}{$\begin{array}{l}\text { (Alman- } \\
\text { gush et al, } \\
2015 \mathrm{~b}) \\
\text { Finland } \\
\text { and Brazil }\end{array}$} & 311 & cT1-2N0 & Tongue & $\begin{array}{l}57 \\
\text { months }\end{array}$ & Surgery & $\mathrm{H}-\mathrm{E}$ & 5 buds & $30.9 \%$ & $\times 20$ & DSS & $\begin{array}{c}2.59 \\
(1.58-4.26) \\
1.76 \\
(1.01-3.06)\end{array}$ & $\begin{array}{c}<0.001 \\
0.044\end{array}$ & 7 \\
\hline & & & & & & & & & & DFS & $\begin{array}{c}1.85(1.21-2.82) \\
1.80 \\
(1.10-2.93)\end{array}$ & $\begin{array}{l}0.005 \\
0.020\end{array}$ & \\
\hline & & & & & & & & & & $\mathrm{OS}^{\mathrm{a}}$ & $\begin{array}{c}1.40 \\
(1.01-1.93) \\
1.62 \\
(1.17-2.25) \\
\end{array}$ & $\begin{array}{l}0.042 \\
0.004\end{array}$ & \\
\hline $\begin{array}{l}\text { (Angadi } \\
\text { et al, 2015) } \\
\text { India }\end{array}$ & 75 & T1-T4 & $\begin{array}{l}\text { Oral } \\
\text { cavity }\end{array}$ & NA & Surgery & $\mathrm{H}-\mathrm{E}$ & $\begin{array}{c}10 \\
\text { buds }\end{array}$ & $45.3 \%$ & $\times 25$ & LNM & $\begin{array}{c}\text { OR } 6.79 \\
(2.28-20.18)\end{array}$ & $\begin{array}{c}<0.001 \\
0.001\end{array}$ & 7 \\
\hline $\begin{array}{l}\text { (Attrama- } \\
\text { dal et al, } \\
2015 \text { ) } \\
\text { Norway }\end{array}$ & 58 & cT1-2N0 & $\begin{array}{l}\text { Oral } \\
\text { cavity }\end{array}$ & $\begin{array}{l}55 \\
\text { months }\end{array}$ & Surgery & $\mathrm{IHC}$ & 5 buds & $51.7 \%$ & $\times 20$ & DFS & NA & 0.043 & 5 \\
\hline \multirow[t]{3}{*}{$\begin{array}{l}\text { (Jensen } \\
\text { et al, } \\
\text { 2015a) } \\
\text { Denmark }\end{array}$} & 199 & T1-T4 & $\begin{array}{l}\text { Tongue } \\
\text { and floor } \\
\text { of mouth }\end{array}$ & $\begin{array}{l}4.6 \\
\text { years }\end{array}$ & Surgery & $\mathrm{IHC}$ & $\begin{array}{c}\text { Median } \\
\text { bud } \\
\text { count }\end{array}$ & $50.3 \%$ & $\begin{array}{r}\times 20 \\
(\mathrm{DIA})\end{array}$ & LNM & $\begin{array}{c}\text { AUC of } 0.69 \\
(95 \% \mathrm{Cl} \\
0.61-0.76)\end{array}$ & NA & 8 \\
\hline & & & & & & & & & & OS & $\begin{array}{l}1.8(1.3-2.6) \\
1.6(1.1-2.3)\end{array}$ & 0.01 & \\
\hline & & & & & & & & & & DFS & $2.1(1.2-3.6)$ & $<0.01$ & \\
\hline \multirow[t]{3}{*}{$\begin{array}{l}\text { (Xie et al, } \\
\text { 2015) } \\
\text { China }\end{array}$} & $\begin{array}{c}195 \\
(106 \\
\text { with } \\
\text { follow } \\
\text { up) }\end{array}$ & cT1-2N0 & Tongue & $\begin{array}{l}56 \\
\text { months }\end{array}$ & Surgery & $\mathrm{IHC}$ & 5 buds & $52.8 \%$ & $\times 20$ & $\begin{array}{l}\text { Occult } \\
\text { LNM }\end{array}$ & NA & 0.015 & 7 \\
\hline & & & & & & & & & & $\begin{array}{l}\text { Local } \\
\text { relapse }\end{array}$ & NA & 0.001 & \\
\hline & & & & & & & & & & OS & $\begin{array}{c}10.44 \\
(2.43-44.88) \\
5.58 \\
(1.23-25.38) \\
\end{array}$ & $\begin{array}{l}0.002 \\
0.026\end{array}$ & \\
\hline $\begin{array}{l}\text { (Nandita } \\
\text { et al, 2016) } \\
\text { India }\end{array}$ & 30 & NA & $\begin{array}{l}\text { Oral } \\
\text { cavity }\end{array}$ & NA & NA & $\mathrm{H}-\mathrm{E}$ & 5 buds & NA & NA & OS & NA & NA & 3 \\
\hline \multirow[t]{3}{*}{$\begin{array}{l}\text { (Seki et al, } \\
\text { 2016) } \\
\text { Japan }\end{array}$} & 91 & T1-T4 & $\begin{array}{l}\text { Tongue } \\
\text { and floor } \\
\text { of mouth } \\
\text { (biopsy) }\end{array}$ & $\begin{array}{l}\text { From } 4 \\
\text { months } \\
\text { to } 5 \\
\text { years }\end{array}$ & $\begin{array}{l}\text { Surgery; } 47 \\
\text { cases } \\
\text { received } \\
\text { preoperative } \\
\text { CT }\end{array}$ & $\mathrm{IHC}$ & 3 buds & $50.5 \%$ & $\times 20$ & LNM & $\begin{array}{c}\text { Univariate: NA } \\
\text { OR } 31 \\
(2.6-331.8)\end{array}$ & $<0.01$ & 6 \\
\hline & & & & & & & & & & OS & NA & $<0.05$ & \\
\hline & & & & & & & & & & RFS & NA & $<0.01$ & \\
\hline $\begin{array}{l}\text { (Xie et al, } \\
\text { 2016) } \\
\text { China }\end{array}$ & 100 & T1-T4 & Tongue & 3 years & Surgery & $\mathrm{H}-\mathrm{E}, \mathrm{IHC}$ & 5 buds & $49 \%$ & $\times 20$ & OS & $\begin{array}{c}2.23 \\
(0.99-5.01)\end{array}$ & 0.046 & \\
\hline
\end{tabular}




\section{Table 2. (Continued)}

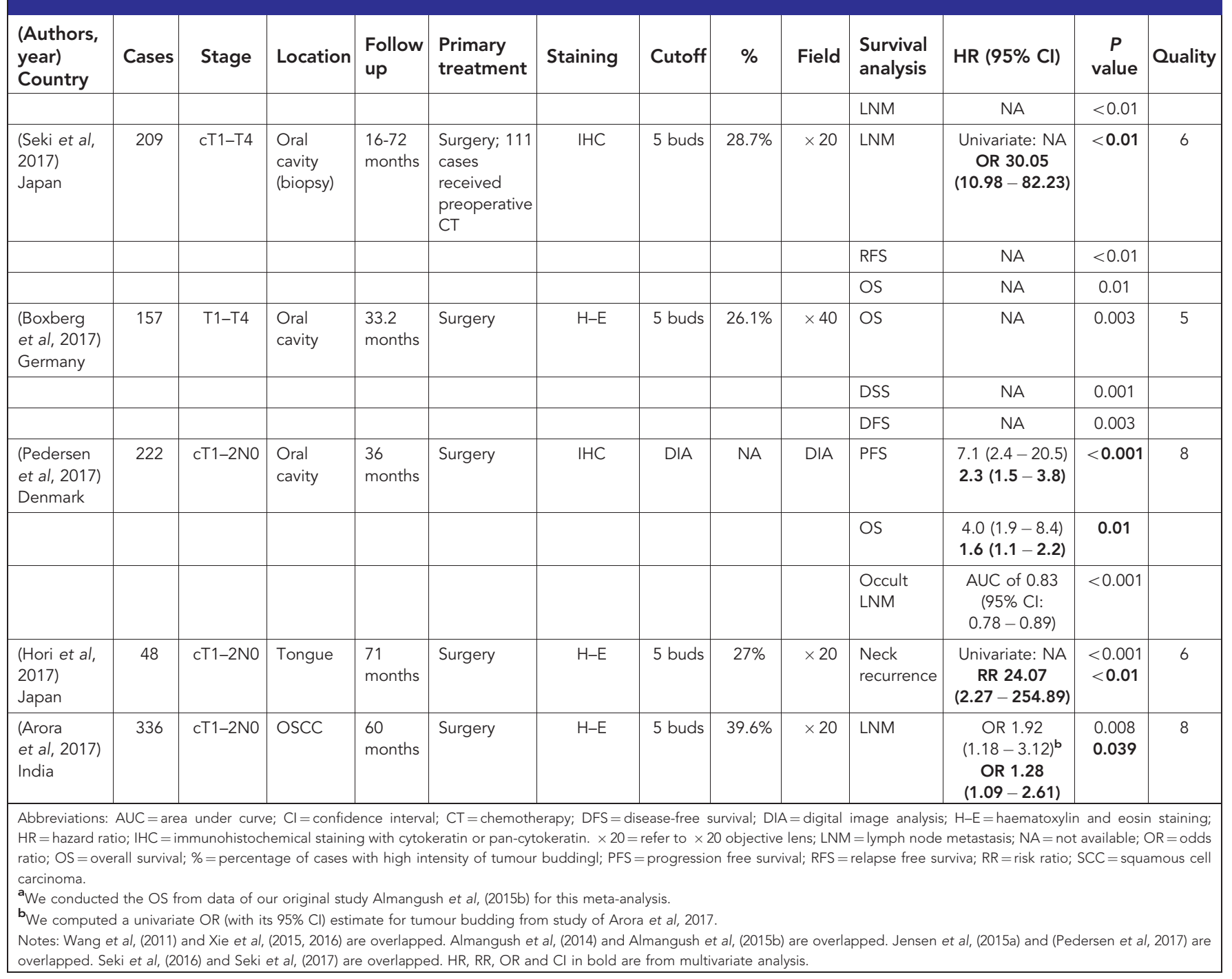

tumour budding was significantly associated with the presence of lymph node metastasis (Figure 3A) when compared with lowgrade tumour budding $(\mathrm{OR}=7.08,95 \% \mathrm{CI}=1.75-28.73)$. Subsequently, our meta-analysis of studies (Arora et al, 2017; Seki et al, 2017) that used a cutoff point of five buds (Figure 3B) and our pooled analysis of the other studies (Angadi et al, 2015; Manjula et al, 2015) that used a cutoff point of 10 buds (Figure 3C) showed similar odds ratios $(\mathrm{OR}=7.32,95 \% \mathrm{CI}=0.49-108.35$; and $\mathrm{OR}=7.0,95 \% \mathrm{CI}=2.84-17.29$, respectively), while the former analysis was more heterogeneous.

The pooled analysis for disease-free survival (Figure 4) also showed that high-grade tumour budding was correlated with poorer survival $(\mathrm{HR}=1.83,95 \% \mathrm{CI}=1.34-2.50)$. For overall survival, tumour budding was associated with poor survival when all stages (Figure $5 \mathrm{~A}$ ) were included $(\mathrm{HR}=1.88,95 \% \mathrm{CI}=1.25-$ 2.82 ) and also when a meta-analysis of early stage (Figure $5 \mathrm{~B}$ ) cases only was performed $(\mathrm{HR}=3.27,95 \% \mathrm{CI}=1.12-9.55)$. The pooled analyses for overall survival of the studies that evaluated tumour budding in oral tongue cancers using five buds as a cutoff point also showed similar results (Figure 5C) when advanced stage was included $(\mathrm{HR}=2.07,95 \% \mathrm{CI}=0.88-4.85)$, as well as when studies of early stage cases (Figure 5D) were analysed separately $(\mathrm{HR}=3.35,95 \% \mathrm{CI}=0.48-23.62)$.
We observed potential heterogeneity $\left(I^{2} \geqslant 66 \%\right)$ between the studies for two analyses of lymph node metastasis (Figure 3A and B) and for overall survival meta-analyses (Figure 5), but we could not assess statistical significance of heterogeneity due to the small number of studies. Of note, for one meta-analysis of lymph node metastasis (Figure 3C), as well as for disease-free survival metaanalysis (Figure 4), we did not observe heterogeneity between the studies $\left(I^{2}=0\right)$.

\section{DISCUSSION}

The invasive tumour front of OSCC has been an area of research interest in recent decades. Cancer cells at the IF behave aggressively compared with cancer cells in the superficial or central regions of the main tumour mass (Bryne et al, 1992; Jensen et al, 2015a). In addition, cancer cells at the IF may undergo epithelialmesenchymal transition, which is an important step in progression of tumour metastasis (Christofori, 2006). Tumour budding that may be involved in development of metastasis has been reported at the IF and evaluated in several studies on OSCC (Table 2). Here, we performed a meta-analysis on the results of such studies. Our 
Table 3. Summary of the studies evaluated tumour budding in OSCC without analysis of its prognostic value

\begin{tabular}{|c|c|c|c|c|c|c|c|c|c|c|}
\hline $\begin{array}{l}\text { (Authors, } \\
\text { year) } \\
\text { Country }\end{array}$ & Cases & Stage & Location & $\begin{array}{l}\text { Follow } \\
\text { up }\end{array}$ & $\begin{array}{l}\text { Primary } \\
\text { treatment }\end{array}$ & Staining & Cutoff & $\%$ & Field & Findings related to tumour budding \\
\hline $\begin{array}{l}\text { (Marangon } \\
\text { Junior et al, } \\
\text { 2014) } \\
\text { Brazil }\end{array}$ & 57 & NA & $\begin{array}{l}\text { Oral } \\
\text { cavity }\end{array}$ & NA & NA & $\mathrm{IHC}$ & 5 buds & $75.4 \%$ & $\times 20$ & $\begin{array}{l}\text { High intensity tumour budding is } \\
\text { associated with higher density of stromal } \\
\text { myofibroblasts and higher expression of } \\
\text { laminin- } 5 \text { gamma } 2 \text { chain }\end{array}$ \\
\hline $\begin{array}{l}\text { (Sawazaki- } \\
\text { Calone } \\
\text { et al, 2015) } \\
\text { Brazil }\end{array}$ & 113 & $\mathrm{~T} 1-\mathrm{T} 4$ & $\begin{array}{l}\text { Oral } \\
\text { cavity }\end{array}$ & 5 years & Surgery & $\mathrm{H}-\mathrm{E}$ & 5 buds & NA & $\times 20$ & $\begin{array}{l}\text { Tumour budding is a parameter of the } \\
\text { budding-depth (BD) prognostic model. BD } \\
\text { showed a superior prognostic value } \\
\text { compared to other histopathologic } \\
\text { grading systems }\end{array}$ \\
\hline $\begin{array}{l}\text { (Jensen } \\
\text { et al, } \\
\text { 2015b) } \\
\text { Denmark }\end{array}$ & 28 & NA & $\begin{array}{l}\text { Oral } \\
\text { cavity }\end{array}$ & NA & NA & $\mathrm{IHC}$ & NA & NA & NA & $\begin{array}{l}\text { A relationship between tumour budding } \\
\text { and myofibroblasts was seen but was not a } \\
\text { general featureBudding cells have shown } \\
\text { low expression of E-cadherin }\end{array}$ \\
\hline $\begin{array}{l}\text { (Strieder } \\
\text { et al, 2017) } \\
\text { Brazil }\end{array}$ & 53 & $\mathrm{~T} 1-\mathrm{T} 4$ & Lip & $\begin{array}{l}159.4 \\
\text { months } \\
\text { or } 57.4 \\
\text { months }\end{array}$ & Surgery & $\mathrm{H}-\mathrm{E}$ & 5 buds & $67.9 \%$ & $\times 20$ & $\begin{array}{l}\text { Tumour budding is a parameter of the } \\
\text { budding-depth (BD) prognostic model. BD } \\
\text { showed a high prognostic value for lip } \\
\text { cancer }\end{array}$ \\
\hline $\begin{array}{l}\text { (Leao et al, } \\
\text { 2017) } \\
\text { Brazil }\end{array}$ & 103 & NA & $\begin{array}{l}\text { Oral } \\
\text { cavity }\end{array}$ & NA & NA & $\mathrm{H}-\mathrm{E} ; \mathrm{IHC}$ & 5 buds & NA & $\times 20$ & $\begin{array}{l}\text { Evaluation of tumour budding by } \mathrm{IHC} \\
\text { showed higher reproducibility and } \\
\text { replicability compared to } \mathrm{H}-\mathrm{E}\end{array}$ \\
\hline
\end{tabular}

meta-analysis shows that tumour budding is a promising prognostic marker for OSCC.

The importance of tumour budding in cancer prognosis has been studied widely particularly in colorectal cancer (Rogers et al, 2016; Lugli et al, 2017), where it is recognised as an additional prognostic marker (Koelzer et al, 2014). In oesophageal cancer (Almangush et al, 2016), pancreatic cancer (Karamitopoulou, 2012), breast cancer (Gujam et al, 2015) and lung cancer (Kadota et al, 2014), tumour budding has been reported as a promising prognostic marker. A significant correlation between high tumour budding count and the presence of lymph node metastases is one of the most important findings observed in OSCC (Figure 3) and in many other cancers (Yamaguchi et al, 2010; Landau et al, 2014; Salhia et al, 2015; Cappellesso et al, 2017). Such a finding might indicate that tumour budding is an early step en route to metastasis. A correlation between tumour budding and occult lymph node metastasis was reported in early stage OSCC (Xie et al, 2015). As occult metastasis is the most common reason for relapse and poor prognosis in early stage cases, it is of great importance to validate this correlation in other large multicentre cohorts.

Simplicity, reproducibility and low cost are important characteristics when considering a new marker for clinical application. The published studies in OSCC and in other cancers repeatedly reported these advantages for tumour budding (Wang et al, 2011; Graham et al, 2015; Almangush et al, 2015b). Another advantage of the studies of tumour budding in OSCC is that their results are consistent with those from the first study that evaluated budding in OSCC (Wang et al, 2011). Conversely, controversial findings were reported for the prognostic biomarkers identified for OSCC (Soland and Brusevold, 2013; Almangush et al, 2017a).

When considering a new prognostic marker for clinical application, the marker should also have a significant prognostic value independent from classical markers. Interestingly, for tumour budding, most of the studies that provided multivariate analysis (Wang et al, 2011; Angadi et al, 2015; Almangush et al, 2015b; Seki et al, 2016; Hori et al, 2017; Pedersen et al, 2017) reported that tumour budding has a superior prognostic value compared to other classical markers such as TNM stage, depth of invasion or WHO tumour grade. However, in one study, (Manjula et al, 2015), tumour thickness (5-mm cutoff point) showed superior prognostic value compared with tumour budding, and the same was observed for depth of invasion in the study by Arora et al. (2017). In another study (Jensen et al, 2015a), advanced stage was associated with a poorer prognosis than in cases with high-grade budding. Of note, in the latter two studies (Jensen et al, 2015a; Arora et al, 2017) tumour budding was also reported as an independent prognostic marker in multivariate analysis. Therefore, multivariate analysis of published studies indicates that high-intensity tumour budding, either independently or in addition to the advanced stage, deeply invaded tumour or both, is associated with poor prognosis of OSCC. Only in the study by Manjula et al. (2015), tumour budding was not a prognostic marker in multivariate analysis. However, Manjula et al. used a 10-bud cutoff point to stratify cases into risk scores, and it is possible that some cases with $\geqslant$ five buds were included in the low-grade budding group, which subsequently reduced the prognostic value of tumour budding in this cohort.

Different methods have been introduced for the evaluation of tumour budding (Koelzer et al, 2014). However, a traditional method was widely used in the studies on OSCC. In this method, the IF is scanned under low magnification $(\times 4)$, and the field with the highest budding number is counted under high magnification $(\times 20)$ and used for the score (Wang et al, 2011). The evaluation of intra-tumoural budding was not reported in OSCC. Of note, intratumoural budding was shown as a valid method in colorectal cancer (Lugli et al, 2011). In only a few studies, evaluation of the prognostic value of tumour budding at the IF was carried out in biopsy specimens of OSCC (Seki et al, 2016, 2017; Almangush et al, 2017b). However, the IF area might not be included in a biopsy specimen. In such cases, another form of tumour budding, the intra-tumoural budding (i.e., tumour budding between tumour islands) might be more applicable. The latter approach may be of great importance from a clinical point of view for treatment 


\section{A}

Study

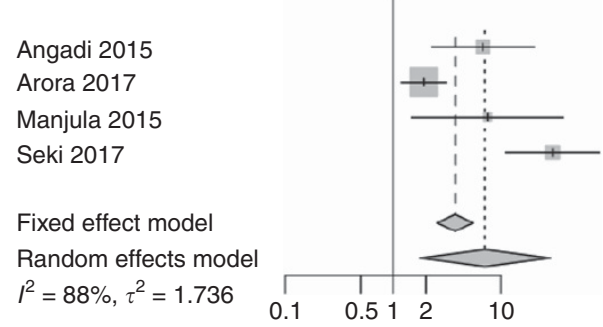

B

\section{Study}

Arora 2017

Seki 2017

Fixed effect model

Random effects model

$I^{2}=96 \%, \tau^{2}=3.62$

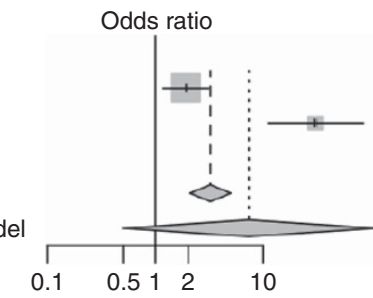

OR

$95 \% \mathrm{Cl}$

$1.92 \quad(1.18 ; 3.12)$

$30.05(10.98 ; 82.23)$

$3.23 \quad(2.08 ; 5.00)$

$7.32(0.49 ; 108.35)$

Ctudy

Angadi 2015

Manjula 2015

Fixed effect model

Random effects model

$I^{2}=0 \%, \tau^{2}=0$

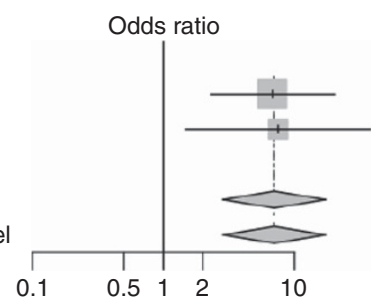

OR

$95 \% \mathrm{Cl}$

$6.79 \quad(2.28 ; 20.20)$

$7.50 \quad(1.49 ; 37.70)$

$7.00 \quad(2.84 ; 17.29)$

$7.00 \quad(2.84 ; 17.29)$

Figure 3. Forest plots for the pooled analyses of the studies evaluated the prognostic value of tumour budding in assessing lymph node metastasis of OSCC. (A) All eligible studies. (B) Studies used five-bud cutoff point. (C) Studies used 10-bud cutoff point.

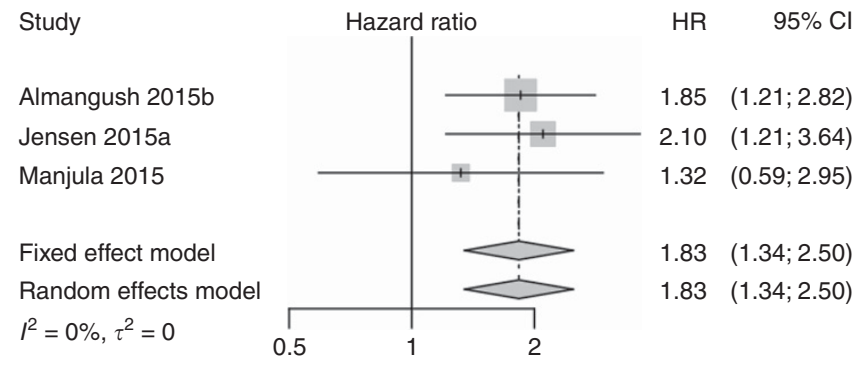

Figure 4. Pooled analysis for disease-free survival.

planning of OSCC, and should be further evaluated. In addition, intraoperative evaluation of tumour budding (i.e., using freshfrozen sections) should also be considered in future studies.

Diverse cutoff points were suggested for stratification of cases into low-grade and high-grade tumour budding (Table 2). In the present studies on OSCC, five-bud cutoff point was the most commonly used (low grade $<5 v$ s high grade $\geqslant 5$ ). We conducted meta-analysis for studies that used different cutoff points (Figure $3 \mathrm{~A}$ ), and then, we conducted separate meta-analyses for studies that used a five-bud cutoff point (Figure 3B) and for studies that used a 10-bud cutoff point (Figure 3C). Interestingly, these meta-analyses show that tumour budding is a useful prognostic marker for OSCC cases. As the risk of poor prognosis begins at the presence of five buds, we suggest considering both five-bud and 10bud cutoff points in further studies to determine which one of these cutoff points is more predictive of poor prognosis and should therefore be used in clinical practice.

Most studies evaluated tumour budding using H-E staining. Interestingly, a recent study on OSCC concluded that evaluation of tumour budding by immunohistochemistry with pan-cytokeratin antibodies (clones AE1/AE3) showed a better reproducibility of results than those with H-E staining (Leao et al, 2017). However, standardisation of the evaluation method and cutoff point is still necessary. A recent international consensus conference on tumour budding (Lugli et al, 2017) made several statements (including definition, evaluation method and others) for reporting tumour budding in colorectal cancer. Such statements are still necessary to allow inclusion of tumour budding in a pathology report for OSCC cases.

The combination of squamous cell carcinoma (SCC) from different subsites of the oral cavity was a common disadvantage among the studies that evaluated tumour budding in OSCC. Therefore, we recommend a separate analysis for each subsite when reporting tumour budding in future studies. Despite a small number of studies available, we conducted a meta-analysis for overall survival of studies that evaluated tumour budding in oral tongue SCC (Figure 5C and D), which is the most common SCC of the oral cavity. The results of this meta-analysis suggest, although without strong statistical evidence, that cases of oral tongue cancer with a high budding index have a poorer overall survival. This is consistent with the other meta-analyses where the subsites were mixed. Another combination that was also common among the included studies was mixing of early stage and late-stage cancers in the same analysis. We conducted a meta-analysis for the two studies that included only early stage cancers (Figure 5D), and the result suggests that tumour budding in such early stage cases has a prognostic value, but given the wide confidence intervals, this result lacks strong statistical evidence and requires further studies for validation.

Tumour budding in OSCC has also been evaluated using digital pathology (Jensen et al, 2015a; Pedersen et al, 2017). Digital image analysis has been used increasingly in recent research and it has shown better accuracy and reproducibility compared with the conventional method as it allows truly quantitative scores (RiberHansen et al, 2012). Moreover, it will be easier to standardise the scoring method using digital image analysis (Pedersen et al, 2017). Therefore, digital image analysis of tumour budding in OSCC should be used to validate results in large cohorts.

Few studies have examined the biological background of tumour budding in OSCC. Immunohistochemical analysis showed that tumour budding is associated with reduced expression of E-cadherin and overexpression of vimentin (Wang et al, 2011). Regarding interactions with the surrounding stroma, high-grade budding was associated with a higher density of stromal myofibroblasts and higher expression of laminin- 5 gamma 2 chain (Marangon Junior et al, 2014). In genetic profiling, decreased expression of $m i R-200 a, m i R-200 b$ and $m i R-200 c$ was reported in cancer cells of tumour budding (Jensen et al, 2015a). However, molecular analyses in other cancers have provided more details about the genetic background of tumour budding (Zlobec and Lugli, 2010; Galvan et al, 2015; Bradley et al, 2016; Miyake et al, 2017), and similar analyses in OSCC are still necessary to better understand this phenomenon.

The main limitation of the current meta-analyses is the small number of the original studies. Accordingly, it was difficult to statistically evaluate the heterogeneity between the studies. To avoid bias due to any potential heterogeneity, we focused on a random effects model that is known as an effective method to combine heterogeneous studies (Guolo and Varin, 2017). In addition, for each meta-analysis (Figures 3-5), we also reported results of a fixed effect model and they were consistent with a random effects model. Moreover, our meta-analyses addressed 


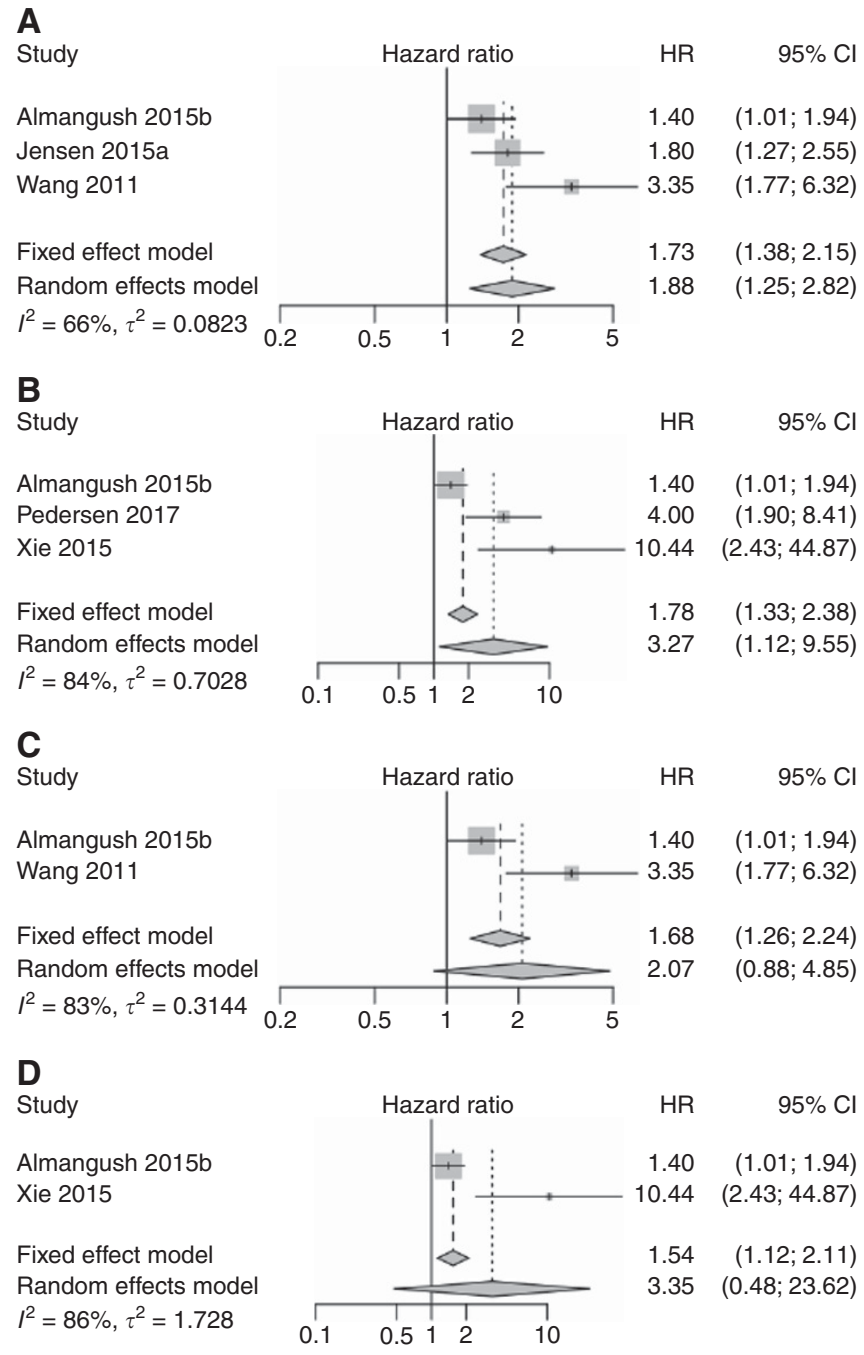

Figure 5. Pooled analyses for overall survival. (A) All stages of OSCC. (B) Pooled analysis for overall survival of OSCC including studies of early stage only. (C) Pooled analysis for overall survival including only oral tongue cancer studies which used five-bud cutoff point. (D) Pooled analysis for overall survival including early stage oral tongue cancer studies that used five-bud cutoff point.

three different end points (metastasis, overall survival and diseasefree survival), and our results regarding the common effect of tumour budding as a negative prognostic marker are valid based on meta-analyses of these different end points. Of note, this effect is also consistent across published studies. Inclusion of different subsites of the oral cavity or mixing of different stages in analysis of the same cohort was another limitation, as mentioned above. The absence of prospective studies was also noted.

Despite these shortcomings, there is sufficient evidence to suggest that OSCCs with high-grade tumour budding are at high risk of poor prognosis. This evidence was prominent and validated in many studies. Similar evidence has also accumulated on the prognostic value of tumour budding in other cancers (Almangush et al, 2016; Rogers et al, 2016; Lugli et al, 2017). To the best of our knowledge, this is the first meta-analysis on the prognostic value of tumour budding in OSCC. We conclude that tumour budding has a prominent prognostic power for OSCC even at early stages of the disease. Future research on OSCC should compare the different evaluation methods with the goal of standardising the assessment method for pathology reports. In addition, understanding the genetic background of tumour budding may facilitate identification of treatment targets in OSCC.
ACKNOWLEDGEMENTS

This work was financially supported by the Finnish Dental Society (Alhadi Almangush), the Rauha Ahokas Foundation (Alhadi Almangush), the Academy of Finland (288509 and 294050 to Matti Pirinen), the Research Funds of the University of Helsinki (Matti Pirinen), the Helsinki University Hospital Research Fund (Antti A Mäkitie and Tuula Salo), the Sigrid Juselius Foundation (Tuula Salo), the Finnish Cancer Society (Tuula Salo) and the Maritza and Reino Salonen Foundation (Ilmo Leivo).

\section{CONFLICT OF INTEREST}

The authors declare no conflict of interest.

REFERENCES

Almangush A, Bello IO, Coletta RD, Makitie AA, Makinen LK, Kauppila JH, Pukkila M, Hagstrom J, Laranne J, Soini Y, Kosma VM, Koivunen P, Kelner N, Kowalski LP, Grenman R, Leivo I, Laara E, Salo T (2015a) For early-stage oral tongue cancer, depth of invasion and worst pattern of invasion are the strongest pathological predictors for locoregional recurrence and mortality. Virchows Arch 467(1): 39-46.

Almangush A, Bello IO, Keski-Santti H, Makinen LK, Kauppila JH, Pukkila M, Hagstrom J, Laranne J, Tommola S, Nieminen O, Soini Y, Kosma VM, Koivunen P, Grenman R, Leivo I, Salo T (2014) Depth of invasion, tumor budding, and worst pattern of invasion: prognostic indicators in early-stage oral tongue cancer. Head Neck 36(6): 811-818.

Almangush A, Coletta RD, Bello IO, Bitu C, Keski-Santti H, Makinen LK, Kauppila JH, Pukkila M, Hagstrom J, Laranne J, Tommola S, Soini Y, Kosma VM, Koivunen P, Kowalski LP, Nieminen P, Grenman R, Leivo I, Salo T (2015b) A simple novel prognostic model for early stage oral tongue cancer. Int J Oral Maxillofac Surg 44(2): 143-150.

Almangush A, Heikkinen I, Makitie AA, Coletta RD, Laara E, Leivo I, Salo T (2017a) Prognostic biomarkers for oral tongue squamous cell carcinoma: a systematic review and meta-analysis. Br J Cancer 117(6): 856-866.

Almangush A, Karhunen M, Hautaniemi S, Salo T, Leivo I (2016) Prognostic value of tumour budding in oesophageal cancer: a meta-analysis. Histopathology 68(2): 173-182.

Almangush A, Leivo I, Siponen M, Sundquist E, Mroueh R, Makitie AA, Soini Y, Haglund C, Nieminen P, Salo T (2017b) Evaluation of the budding and depth of invasion (BD) model in oral tongue cancer biopsies. Virchows Arch; epub ahead of print 2 August 2017; doi:10.1007/s00428017-2212-1.

Altman DG, McShane LM, Sauerbrei W, Taube SE (2012) Reporting recommendations for tumor marker prognostic studies (REMARK): explanation and elaboration. BMC Med 10: 51.

Angadi PV, Patil PV, Hallikeri K, Mallapur MD, Hallikerimath S, Kale AD (2015) Tumor budding is an independent prognostic factor for prediction of lymph node metastasis in oral squamous cell carcinoma. Int J Surg Pathol 23(2): 102-110.

Arora A, Husain N, Bansal A, Neyaz A, Jaiswal R, Jain K, Chaturvedi A, Anand N, Malhotra K, Shukla S (2017) Development of a new outcome prediction model in early-stage squamous cell carcinoma of the oral cavity based on histopathologic parameters with multivariate analysis: the aditinuzhat lymph-node prediction score (ANLPS) system. Am J Surg Pathol 41(7): 950-960.

Attramadal CG, Kumar S, Boysen ME, Dhakal HP, Nesland JM, Bryne M (2015) Tumor budding, EMT and cancer stem cells in T1-2/N0 oral squamous cell carcinomas. Anticancer Res 35(11): 6111-6120.

Boxberg M, Jesinghaus M, Dorfner C, Mogler C, Drecoll E, Warth A, Steiger K, Bollwein C, Meyer P, Wolff KD, Kolk A, Weichert W (2017) Tumor budding activity and cell nest size determine patient outcome in oral squamous cell carcinoma: Proposal for an adjusted grading system. Histopathology 70(7): 1125-1137.

Bradley CA, Dunne PD, Bingham V, McQuaid S, Khawaja H, Craig S, James J, Moore WL, McArt DG, Lawler M, Dasgupta S, Johnston PG, Van Schaeybroeck S (2016) Transcriptional upregulation of c-MET is 
associated with invasion and tumor budding in colorectal cancer. Oncotarget 7(48): 78932-78945.

Bryne M, Koppang HS, Lilleng R, Kjaerheim A (1992) Malignancy grading of the deep invasive margins of oral squamous cell carcinomas has high prognostic value. J Pathol 166(4): 375-381.

Cappellesso R, Luchini C, Veronese N, Mele ML, Rosa-Rizzotto E, Guido E, De Lazzari F, Pilati P, Farinati F, Realdon S, Solmi M, Fassan M, Rugge M (2017) Tumor budding as a risk factor for nodal metastasis in Pt1 colorectal cancers: a meta-analysis. Hum Pathol 65: 62-70.

Chen TC, Wang CP, Ko JY, Yang TL, Hsu CW, Yeh KA, Chang YL, Lou PJ (2013) The impact of perineural invasion and/or lymphovascular invasion on the survival of early-stage oral squamous cell carcinoma patients. Ann Surg Oncol 20(7): 2388-2395.

Christofori G (2006) New signals from the invasive front. Nature 441(7092): $444-450$.

DerSimonian R, Laird N (1986) Meta-analysis in clinical trials. Control Clin Trials 7(3): 177-188.

Ferlay J, Soerjomataram I, Dikshit R, Eser S, Mathers C, Rebelo M, Parkin DM, Forman D, Bray F (2015) Cancer incidence and mortality worldwide: sources, methods and major patterns in GLOBOCAN 2012. Int J Cancer 136(5): E359-E386.

Galvan JA, Zlobec I, Wartenberg M, Lugli A, Gloor B, Perren A, Karamitopoulou E (2015) Expression of E-cadherin repressors SNAIL, ZEB1 and ZEB2 by tumour and stromal cells influences tumour-budding phenotype and suggests heterogeneity of stromal cells in pancreatic cancer. Br J Cancer 112(12): 1944-1950.

Graham RP, Vierkant RA, Tillmans LS, Wang AH, Laird PW, Weisenberger DJ, Lynch CF, French AJ, Slager SL, Raissian Y, Garcia JJ, Kerr SE, Lee HE, Thibodeau SN, Cerhan JR, Limburg PJ, Smyrk TC (2015) Tumor budding in colorectal carcinoma: confirmation of prognostic significance and histologic cutoff in a population-based cohort. Am J Surg Pathol 39(10): $1340-1346$.

Gujam FJ, McMillan DC, Mohammed ZM, Edwards J, Going JJ (2015) The relationship between tumour budding, the tumour microenvironment and survival in patients with invasive ductal breast cancer. $\mathrm{Br} \mathrm{J} \mathrm{Cancer} \mathrm{113(7):}$ 1066-1074.

Guolo A, Varin C (2017) Random-effects meta-analysis: the number of studies matters. Stat Methods Med Res 26(3): 1500-1518.

Higgins JP, Thompson SG (2002) Quantifying heterogeneity in a metaanalysis. Stat Med 21(11): 1539-1558.

Hori Y, Kubota A, Yokose T, Furukawa M, Matsushita T, Takita M, Mitsunaga S, Mizoguchi N, Nonaka T, Nakayama Y, Oridate N (2017) Predictive significance of tumor depth and budding for late lymph node metastases in patients with clinical n0 early oral tongue carcinoma. Head Neck Pathol 11(4): 477-486.

Jensen DH, Dabelsteen E, Specht L, Fiehn AM, Therkildsen MH, Jonson L, Vikesaa J, Nielsen FC, von Buchwald C (2015a) Molecular profiling of tumour budding implicates TGFbeta-mediated epithelial-mesenchymal transition as a therapeutic target in oral squamous cell carcinoma. J Pathol 236(4): 505-516.

Jensen DH, Reibel J, Mackenzie IC, Dabelsteen E (2015b) Single cell migration in oral squamous cell carcinoma - possible evidence of epithelialmesenchymal transition in vivo. J Oral Pathol Med 44(9): 674-679.

Kadota K, Nitadori J, Woo KM, Sima CS, Finley DJ, Rusch VW, Adusumilli PS, Travis WD (2014) Comprehensive pathological analyses in lung squamous cell carcinoma: single cell invasion, nuclear diameter, and tumor budding are independent prognostic factors for worse outcomes. J Thorac Oncol 9(8): 1126-1139.

Kadota K, Yeh YC, Villena-Vargas J, Cherkassky L, Drill EN, Sima CS, Jones DR, Travis WD, Adusumilli PS (2015) Tumor budding correlates with the protumor immune microenvironment and is an independent prognostic factor for recurrence of stage i lung adenocarcinoma. Chest 148(3): 711-721.

Karamitopoulou E (2012) Tumor budding cells, cancer stem cells and epithelial-mesenchymal transition-type cells in pancreatic cancer. Front Oncol 2: 209 .

Koelzer VH, Langer R, Zlobec I, Lugli A (2014) Tumor budding in upper gastrointestinal carcinomas. Front Oncol 4: 216.

Korvala J, Jee K, Porkola E, Almangush A, Mosakhani N, Bitu C, Cervigne NK, Zandonadi FS, Meirelles GV, Leme AF, Coletta RD, Leivo I, Salo T (2017) MicroRNA and protein profiles in invasive versus noninvasive oral tongue squamous cell carcinoma cells in vitro. Exp Cell Res 350(1): 9-18.
Landau MS, Hastings SM, Foxwell TJ, Luketich JD, Nason KS, Davison JM (2014) Tumor budding is associated with an increased risk of lymph node metastasis and poor prognosis in superficial esophageal adenocarcinoma. Mod Pathol 27(12): 1578-1589.

Leao PL, Marangon Junior H, Melo VV, Caixeta AB, Souza PE, de Aguiar MC, Horta MC (2017) Reproducibility, repeatability and level of difficulty of two methods for tumor budding evaluation in oral squamous cell carcinoma. J Oral Pathol Med 46(10): 949-955.

Lugli A, Kirsch R, Ajioka Y, Bosman F, Cathomas G, Dawson H, El Zimaity H, Flejou JF, Hansen TP, Hartmann A, Kakar S, Langner C, Nagtegaal I, Puppa G, Riddell R, Ristimaki A, Sheahan K, Smyrk T, Sugihara K, Terris B, Ueno H, Vieth M, Zlobec I, Quirke P (2017) Recommendations for reporting tumor budding in colorectal cancer based on the International Tumor Budding Consensus Conference (ITBCC) 2016. Mod Pathol 30(9): 1299-1311.

Lugli A, Vlajnic T, Giger O, Karamitopoulou E, Patsouris ES, Peros G, Terracciano LM, Zlobec I (2011) Intratumoral budding as a potential parameter of tumor progression in mismatch repair-proficient and mismatch repair-deficient colorectal cancer patients. Hum Pathol 42(12): 1833-1840.

Manjula BV, Augustine S, Selvam S, Mohan AM (2015) Prognostic and predictive factors in gingivo buccal complex squamous cell carcinoma: role of tumor budding and pattern of invasion. Indian J Otolaryngol Head Neck Surg 67(Suppl 1): 98-104.

Marangon Junior H, Rocha VN, Leite CF, de Aguiar MC, Souza PE, Horta MC (2014) Laminin-5gamma 2 chain expression is associated with intensity of tumor budding and density of stromal myofibroblasts in oral squamous cell carcinoma. J Oral Pathol Med 43(3): 199-204.

Miyake M, Hori S, Morizawa Y, Tatsumi Y, Toritsuka M, Ohnishi S, Shimada K, Furuya H, Khadka VS, Deng Y, Ohnishi K, Iida K, Gotoh D, Nakai Y, Inoue T, Anai S, Torimoto K, Aoki K, Tanaka N, Konishi N, Fujimoto K (2017) Collagen type IV alpha 1 (COL4A1) and collagen type XIII alpha 1 (COL13A1) produced in cancer cells promote tumor budding at the invasion front in human urothelial carcinoma of the bladder. Oncotarget 8(22): 36099-36114.

Moher D, Liberati A, Tetzlaff J, Altman DG. Group P (2009) Preferred reporting items for systematic reviews and meta-analyses: the PRISMA statement. BMJ 339: b2535.

Muller S, Pan Y, Li R, Chi AC (2008) Changing trends in oral squamous cell carcinoma with particular reference to young patients: 1971-2006. The Emory University experience. Head Neck Pathol 2(2): 60-66.

Nandita KP, Boaz K, Srikant N, Lewis AJ, Manaktala N (2016) Tumour budding: a promising parameter in oral squamous cell carcinoma. Res $J$ Pharm Biol Chem Sci 7(5): 2059-2063.

Pedersen NJ, Jensen DH, Lelkaitis G, Kiss K, Charabi B, Specht L, von Buchwald C (2017) Construction of a pathological risk model of occult lymph node metastases for prognostication by semi-automated image analysis of tumor budding in early-stage oral squamous cell carcinoma. Oncotarget 8(11): 18227-18237.

Riber-Hansen R, Vainer B, Steiniche T (2012) Digital image analysis: a review of reproducibility, stability and basic requirements for optimal results. APMIS 120(4): 276-289.

Rogers AC, Winter DC, Heeney A, Gibbons D, Lugli A, Puppa G, Sheahan K (2016) Systematic review and meta-analysis of the impact of tumour budding in colorectal cancer. Br J Cancer 115(7): 831-840.

Salhia B, Trippel M, Pfaltz K, Cihoric N, Grogg A, Ladrach C, Zlobec I, Tapia C (2015) High tumor budding stratifies breast cancer with metastatic properties. Breast Cancer Res Treat 150(2): 363-371.

Sawazaki-Calone I, Rangel A, Bueno AG, Morais CF, Nagai HM, Kunz RP, Souza RL, Rutkauskis L, Salo T, Almangush A, Coletta RD (2015) The prognostic value of histopathological grading systems in oral squamous cell carcinomas. Oral Dis 21(6): 755-761.

Seki M, Sano T, Yokoo S, Oyama T (2016) Histologic assessment of tumor budding in preoperative biopsies to predict nodal metastasis in squamous cell carcinoma of the tongue and floor of the mouth. Head Neck 38(Suppl 1): E1582-E1590.

Seki M, Sano T, Yokoo S, Oyama T (2017) Tumour budding evaluated in biopsy specimens is a useful predictor of prognosis in patients with cN0 early stage oral squamous cell carcinoma. Histopathology 70(6): 869-879.

Soland TM, Brusevold IJ (2013) Prognostic molecular markers in cancer - quo vadis? Histopathology 63(3): 297-308.

Strieder L, Coutinho-Camillo CM, Costa V, da Cruz Perez DE, Kowalski LP, Kaminagakura E (2017) Comparative analysis of three histologic grading methods for squamous cell carcinoma of the lip. Oral Dis 23(1): 120-125. 
Wang C, Huang H, Huang Z, Wang A, Chen X, Huang L, Zhou X, Liu X (2011) Tumor budding correlates with poor prognosis and epithelialmesenchymal transition in tongue squamous cell carcinoma. J Oral Pathol Med 40(7): 545-551.

Xie N, Wang C, Liu X, Li R, Hou J, Chen X, Huang H (2015) Tumor budding correlates with occult cervical lymph node metastasis and poor prognosis in clinical early-stage tongue squamous cell carcinoma. J Oral Pathol Med 44(4): 266-272.

Xie N, Wang C, Zhuang Z, Hou J, Liu X, Wu Y, Liu H, Huang H (2016) Decreased miR-320a promotes invasion and metastasis of tumor budding cells in tongue squamous cell carcinoma. Oncotarget 7(40): 65744-65757.

Yamaguchi Y, Ishii G, Kojima M, Yoh K, Otsuka H, Otaki Y, Aokage K, Yanagi S, Nagai K, Nishiwaki Y, Ochiai A (2010) Histopathologic features of the tumor budding in adenocarcinoma of the lung: tumor budding as an index to predict the potential aggressiveness. J Thorac Oncol 5(9): 1361-1368.
Zhang P, Zhang L, Liu H, Zhao L, Li Y, Shen JX, Liu Q, Liu MZ, Xi M (2016) Clinicopathologic characteristics and prognosis of tongue squamous cell carcinoma in patients with and without a history of radiation for nasopharyngeal carcinoma: a matched case-control study. Cancer Res Treat 49(3): 695-705.

Zlobec I, Lugli A (2010) Epithelial mesenchymal transition and tumor budding in aggressive colorectal cancer: tumor budding as oncotarget. Oncotarget 1(7): 651-661.

This work is published under the standard license to publish agreement. After 12 months the work will become freely available and the license terms will switch to a Creative Commons AttributionNonCommercial-Share Alike 4.0 Unported License. 